\title{
Analysis on Current Situation and Countermeasures of P2P Network Lending Development in Our Country
}

\author{
Xiaoyan $\mathrm{Fu}$ \\ College of Jincheng \\ Nanjing University of Aeronautics and Astronautics \\ Nanjing, China 210000
}

\begin{abstract}
In recent years, with rapid development of network information technology, as a kind of new type internet financial model, P2P network lending develops very fast in our country. The existence and development of it not only expand investment channel of private capital, but also relieve the difficulty for small and micro businesses to raise capital and make up for deficiency of traditional finance. But because of lacking related laws and regulations, effective supervision system, P2P network lending platforms frequently appear risks such as difficulty in withdrawing deposit and making off with money that harm the stable operation of network lending platforms. This article analyzes current situation of P2P network lending development, discusses problems existing in network lending development of our country and puts forward countermeasures to drive sound development of network lending.
\end{abstract}

Keywords-P2P network lending; current situation; countermeasures

\section{INTRODUCTION}

Because of extensive application of network technology, a new type of internet financial model, P2P network borrowing that depends on network platforms came out in Britain in 2005. The so-called network borrowing refers to "Peer to Peer Lending". It is a kind of lending realized through internet from peer-to-peer. Specifically speaking, Peer to Peer Lending refers to the financing mode that borrowers offer information such as borrowing balance, time and interests to network lending platforms and provide corresponding documentary evidence required by platforms, which identify borrowers according to fixed credit rating model; lenders lend funds through comparing objects of network platforms according to their risk preference. The appearance of this mode is by no accident. In formal financial system, the positioning of financial institutions on the market still lays particular stress on big cities, big enterprises, big groups and big customers and neglects financial demands of small and micro businesses and vulnerable groups. P2P uses "small amount, flexible, efficient, short-term" principles to better build bridges between private capital and small and micro businesses and vulnerable groups, becomes new channel for small and micro businesses and vulnerable groups to raise funds and beneficial supplement of traditional financial system. At present, P2P network lending platform develops rapidly in our country and the scope of influence is extensive increasingly.

\section{CurRent Situation OF P2P Network LENDING DEVELOPMENT IN OUR COUNTRY}

\section{A. Overall Feature of P2P Network Lending Development in Our Country at the Present Stage}

1) Number of network lending platforms increases very fast, with obvious regional characteristics: In 2007, "PPDAI", the first network lending platform was established in Shanghai. Afterwards, "CreditEase" in Beijing and "HONGLING CAPITAL" in Shenzhen set up one after another. Network lending develops rapidly in our country with special force of new things. In recent two years, it shows the situation of high-speed growth. According to data released by Home of Network Loan, up to the end of December 2015, the operation platforms in network lending industry had reached 2,595, which increased 1,020 by comparing with the number in the end of 2014. The absolute increment surpasses that of 2014. From the perspective of regional distribution of P2P network lending platforms, most of them are scattered in eastern coastal areas with developed economy and large capital requirements. Up to the end of December 2015, Guangdong, Shandong and Beijing ranked the top three of our nation with numbers of operation platforms of 476, 329 and 302 respectively, which account for $42.66 \%$ of the number of total platforms in our country. With development policies gradually introduced to support online financing, network lending in inland provinces such as Hubei, Sichuan and Guizhou also showed rapid development in 2015. According to these statistics, it is not difficult to find that most P2P network lending platforms are located in areas with the most developed economy of our country. The distribution mainly depends on economic vitality of the region and the degree for the public to accept online financing.

2) The trading volume and loan balance of network lending platforms increase ceaselessly: According to statistics 
released by the Home of Network Loan, in April 2016, P2P network lending industry realizes overall trading volume of 143,091 billion yuan, which rises $4.90 \%$ by comparing with that of March 2016 and it is 2.59 times of trading volume in April 2015. The monthly trading volume recreates historical high. Until the end of April 2016, cumulative trading volume of P2P network lending industry in history has reached $1,888.118$ billion yuan. The cumulative trading volume from January to April in 2016 reaches 522.897 billion yuan, which is 3.01 times of cumulative trading volume from January to April in last year. With steady rising of trading volume of network lending, the loan balance of P2P network lending industry also increases accordingly. In the end of March 2016, the loan balance reaches 503.977 billion yuan. In the end of April 2016, the loan balance of network lending industry reaches 547.809 billion yuan, which increases $8.70 \%$ of link relative ratio by comparing with that of the end of last month. According to tendency "figure. 1" of loan balance of network lending from January to April in 2016, we can see that there are still steady growth of about 30 to 40 billion yuan. It shows that the funds continuously flow into P2P network lending industry. According to growth rate of loan balance of network lending since 2016, it is predicted that until the end of 2016, the loan balance of network lending will break through 1,000 billion yuan. According to these statistics, it is not difficult to see that network lending industry attracts a large number of investors, who are very confident in the development of P2P network lending industry.

Unit: 0.1 billion yuan

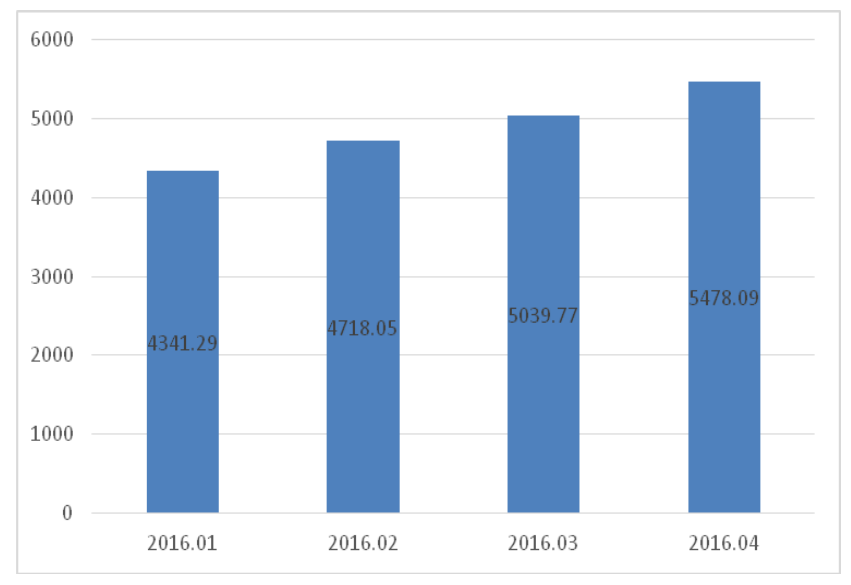

Fig. 1. Loan balance of network lending from January to April in 2016

Data resource: Home of Network Loan

3) The borrowing contents of platforms are flexible and the borrowing rate is relatively high: In P2P network lending, the supply side of fund and demand side of fund directly establish debtor-creditor relationship, so the debtor-creditor relationship is flattening. The capital chain is relatively short with high efficiency. The borrowing contents are more flexible than that of bank credit, which mainly embodies in the following aspects: Firstly, the allotted time of borrowing is flexible, one to 36 months; secondly, the products are rich and colorful. Taking "peer-to-peer lender" as an example, there is wage loan suitable for wage-earning class, Business Loans suitable for private entrepreneur and e-businessman loan suitable for commercial tenants of Taobao online stores; thirdly, the borrowing balance is not high, about one to 500 thousand; fourthly, the efficiency of loan approval is high and it is quick to make loans. The loan approval time is one to three working days. The speed of making loans of LUFAX is the fastest and the fund will be transferred into account in one day. Compared with banks, the lending rate of P2P network lending platforms is relatively high, with annual interest rate of $10 \%$ to $24 \%$. The interest rate of some P2P network lending platforms is too high, close to the level of usurious loan specified by our country. According to statistics of Home of Network Loan, the lending rates of more than ten platforms in front rank are within $20 \%$ in general, which is four times of lending rate of banks in the corresponding period. High lending rate puts heavy burden on borrowers such as small and micro businesses, which go against sustainable development of small and micro businesses.

4) The number of unqualified platforms increases yearly: The type of "making off with money" accounts for half of the quantity. According to statistics released by Home of Network Loan, it shows that the number of unqualified platforms in 2015 reached 896 , which is 3.26 times of that of 2014. Until May 18, 2016, the number of unqualified P2P network lending platforms exposed has reached 1,630, with cumulative amount to be collected of 72.81 billion yuan. The 1,630 unqualified platforms are distributed in 29 provinces, cities and autonomous regions all over the country. The "Major Parts" are mainly located in coastal areas with developed economy. The number of unqualified platforms in Shandong province is 302, which ranks the first; there are 295 unqualified platforms in Guangdong, which ranks the second. Looking from types of unqualified platforms, the proportion of the type of "making off with money" is the biggest, which reaches up to $48.7 \%$; the type of "difficulty in withdrawing deposit" ranks the second, with $29.3 \%$.

\section{B. General Situation of Operation Pattern of P2P Network Lending Platforms in Our Country}

There are nearly one thousand P2P network lending platforms in China. The patterns of network lending platforms are different according to different classification standard. According to level of intimacy between business and network tie, domestic operation pattern of network lending platforms can be classified into the following three kinds.

1) Online mode refers to pure mediator pattern: $\mathrm{P} 2 \mathrm{P}$ network lending platforms only serve as mediator of service to bring lending and borrowing parties together and provide virtual places to offer price, bid, and promise and sign contract for debtors and creditors to conclude the transaction. All lending transactions are completed online. This operation pattern has relatively low transaction cost and fully exert the 
advantages of internet, such as "PPDAI", "peer-to-peer lender" and "leerw.com".

2) Offline mode refers to the mode of "assignment of debt": Under this mode, the official website mainly publicizes. The businesses are mainly carried out offline. The debtor and creditor do not directly sign contract of claims and debts. The third party makes loans for demanders of funds in advance and transfers creditor's rights to investors, such as "CreditEase". Under this mode, network lending platforms connect assets as well as creditor's rights. Coefficient of balance means that the amount of lending must be larger than or equal to creditor's rights transferred. It is obvious that the biggest difference between online mode and offline mode is that network platform in offline mode is not only the intermediary agent of loan, but directly participates in the transaction.

3) Online and offline combination mode means obtaining funds and selling loans online and looking for and choosing customers, getting loan item and auditing item offline, such as "LUFAX": In this mode, internet only plays the role of absorbing and storing funds. The core of credit transaction means that the evaluation of borrowers' credit and loan repayment ability universally adopts the way of offline auditing. Because the credit environment in China is not good, and the credit reference system of Central Bank does not open to non-financial institutions, offline business can let platforms more directly grasp qualification of customers and the pressing for payment at later period also become more rapid and effective, and then reduce bad debt rate. Therefore, most domestic P2P network lending platforms use this mode.

\section{MAIN PROBlems Existing IN P2P NeTwork LENDING DEVELOPMENT OF OUR COUNTRY}

With rapid rise of number and transaction scale of $\mathrm{P} 2 \mathrm{P}$ network lending platforms in our country, risk events in $\mathrm{P} 2 \mathrm{P}$ network lending industry happen frequently. It shows that in order to realize sound development of P2P network lending, it is necessary to recognize problems and risks existing in $\mathrm{P} 2 \mathrm{P}$ network lending development at the present stage.

\section{A. Network Lending Platforms Lack Credit Rating Standard and Individual Credit Reporting System}

The reason why the new type financing mode of network lending can flourish in Britain and America is that Britain and America have very perfect and mature individual credit information system and strict credit rating standard. Zopa in Britain strictly divides the credit of borrowers into four grades. Lenders choose the target borrower according to credit rating, borrowing balance and term of borrowing of borrowers. Prosper in America divides credit rating of all borrowers into seven grades from high to low successively and determines lending rate. While in our country, network lending platforms often use credit accumulation of borrowers in this website to evaluate the credit of borrower. Without unified credit rating standard, it is not objective. At the meantime, the basic credit data of civics in individual credit reporting system of our country is not perfect. In addition, according to relevant provisions of our country, individual credit reporting system does not open to $\mathrm{P} 2 \mathrm{P}$ network lending platforms. It will inevitably make operating cost of P2P network lending platforms increase and make them face very high credit risks.

\section{B. Network Lending Platforms May Appear Liquidity Risk}

Most investors prefer to types of investment with short term and high profit, while borrowers prefer to borrowing requirement with long term and low cost. Therefore, in order to attract customers and increase volume of business, network lending platforms will often use means of term mismatch and amount mismatch to divide long-term borrowing object into short-term borrowing object and divide borrowing object with large amount of money into borrowing object with small amount. It is similar to establish a capital pool that can realize short-term assets and long-term investments. However, during the period of operation, once the investors withdraw deposit intensively, it is very easy to appear liquidity risk. Platforms such as "Wangying Offine" and "Zhongcai Online" appear liquidity risk because they turn long-term borrowing object into short term and turn large amount of money into small amount.

\section{Fund Security on Network Lending Platforms Is Not Guaranteed}

Most network lending platforms in our country introduce third party payment to provide fund payment for lending and borrowing parties. That is to say, the funds of lender will not be transferred to the account of borrower directly, but to the account of lending platform through third party payment institutions. After lending platforms raise the number required by borrower and all funds of acceptable rate, the funds will be transferred to the account of borrower. Obviously, in the process of network lending transactions, the incoming and outgoings of loan fund have time difference. It will lead to the situation that a lot of funds are deposited in account of network lending platform and mix with self-owned funds in platforms. It provides opportunities for "self fusion" and "false fusion" of platforms and also buries hidden trouble for platforms to embezzle these funds or make off with money. The security of precipitation funds on platforms is not guaranteed.

\section{Network Lending Platforms Have the Risk of Money Laundering}

The rapid expansion of network lending platforms in our country meets the requirements of petty loan and provides new channel for money laundering activities. It mainly has the following reasons: Firstly, virtual network environment offers cover for money laundering; secondly, it is difficult to investigate legality of capital source. Even funds acquired from crimes such as smuggling and stealing can be invested and lent on network lending platforms; thirdly, it lacks sufficient inspection for real purpose of loans is insufficient. In the process of capital loan, although network lending platforms require borrowers to ensure the final usable range of funds shall conform to purpose registered in declaration, in order to save cost, platforms only care about repayment of funds. The review process for use of funds exists in name 
only. To sum up, P2P network lending platforms in our country offer space for money laundering activities.

\section{COUNTERMEASURES TO PROMOTE SOUND DEVELOPMENT OF P2P NETWORK LENDING PLATFORMS IN OUR COUNTRY}

\section{A. Improve Related Legal System and Supervision System}

At present, problems and risks existing in network lending operation cannot be neglected. It has been extremely urgent to make laws and supervise pertinently. Therefore, in order to standardize development of P2P network lending industry, the task of top priority is to formally introduce corresponding legal systems and stipulate permitting qualification, business scope and operation pattern as well as withdrawal mechanism of network lending platforms in detail and govern operating management of network lending platforms by law. Meanwhile, national financial supervision agencies such as China Banking Regulatory Commission and People's Bank of China shall establish supervision organizations, issue licenses of financial intermediaries for $\mathrm{P} 2 \mathrm{P}$ network lending platforms and guarantee normative development of network lending platforms. Supervision organizations shall also set up supervision index system of P2P network lending to supervise trading volume, interest rate, bad debt rate and intended use of loans of P2P network lending platforms, timely monitor risk status of P2P network lending platforms and effectively prevent self fusion, false fusion and money laundering activities through network lending platforms.

\section{B. Improve Construction of Credit Reference System and Unify Credit Rating Standard}

Scientific and reasonable credit rating is the key for $\mathrm{P} 2 \mathrm{P}$ network lending platforms to serve lending and borrowing parties and improve efficiency of investment and financing. Therefore, it is necessary to realize the following two aspects: The first is to allow P2P network lending platforms to inquire credit record of borrower through individual credit reporting system of People's Bank of China and upload information of overdue payment and breach of contract carried out by borrowers in the transaction process to credit reference system to complete credit record. The information is supplement of existing information in credit reference system. The second is to establish unified credit rating standard in P2P network lending industry to carry out unified rating for customers. It can reduce the cost for single network lending platform to establish credit rating system, forbid borrowers with bad credit to cheat on many platforms and greatly reduce credit risks of network lending platforms.

\section{Establish Compulsory System of Loan Loss Provision}

Supervision organizations shall introduce related policies and require $\mathrm{P} 2 \mathrm{P}$ network lending platforms to establish system of reserve fund for risk to respond to liquidity risk. For example, supervision organizations can require platforms to set special account for loan loss provision and put certain proportion of registered capitals and volume of transaction into this account. After the total amount of reserve funds reaches certain proportion of loan balance, they will not withdraw it. Besides, they shall regularly publish information such as source and use of loan loss provision to avoid that it is embezzled.

\section{Establish Third-Party Depository System of Network Loan Funds}

In America, P2P network lending platforms cooperate with banks. Banks issue loans to borrowers directly, which can protect lending and borrowing parties and avoid financial fraud. In future development, P2P network platforms in our country can refer to experience of America, cooperate with financing institutions in banking industry with qualification of third-party depository, entrust specified financing institutions to reserve settlement funds in transaction of clients. Depository banks transfer accounts of borrowing and lending parties according to related regulations and requirements. P2P network lending platforms cannot randomly acquire and transfer capitals of clients. In this way, it sets up firewall between self-owned funds of P2P network lending platforms and capitals of clients and prevents network platforms from embezzling clients' capital and solves problems in fund security.

\section{CONCLUSION}

As a comprehensive platform that applies Internet technology to achieve lending and financing, P2P network lending is an innovative mode of traditional lending. At present, our $\mathrm{P} 2 \mathrm{P}$ network lending platform has got a rapid development, but there are many problems and certain risk in the development. We must not deny the value of P2P network lending for existence and development only because of the emergence of these problems. P2P network lending has many advantages such as flexible and easy lending type and high return on investment, which determine a good prospect of $\mathrm{P} 2 \mathrm{P}$ network lending for development in our country, and it will become the main channel of financing for small and medium and micro enterprises in our country. Therefore, our relevant authorities should take effective measures against the main problems of $\mathrm{P} 2 \mathrm{P}$ network lending in its development to promote the development of $\mathrm{P} 2 \mathrm{P}$ network lending, and fully exert the advantages of $\mathrm{P} 2 \mathrm{P}$ network lending platform to revitalize large-scale spare-and-petty capital in the folk and to provide a strong impetus for our economic development.

\section{REFERENCES}

[1] Lei Jian. Current Situation, Problems and Countermeasures of Supervision and Management of P2P Network Lending Industry Development [J], Financial Foresight, 2014 (8).

[2] Chen Zhiyuan. First Exploration on Current Situation and Development of P2P Network Lending [J], Technological Development of Entreprise, 2015(12).

[3] Feng Junwen, Gao Ruiqiong. Summary on P2P Network Loan Research [J], Technoeconomics and Management Research, 2014(7).

[4] Wu Xinglong. Analysis on Current Situation and Regulatory Path of Network Lending Development in Our Country [J], Financial Management, 2013 (3).

[5] Niu Ruifang. Research on Development Issues and Countermeasures of Network Lending Industry in Our Country [J], Friends of Accounting, 2014(19). 
[6] Ye Xiangrong. Research on Risks and Supervision on Model of P2P Lending [J], Financial Regulation Research, 2014(3). 